\title{
ER $\beta 1$ inhibits metastasis of androgen receptor-positive triple-negative breast cancer by suppressing ZEB1
}

\author{
Wei Song ${ }^{1}$, Lin Tang ${ }^{2}$, Yumei Xu', Qian Sun², Fang Yang ${ }^{2}$ and Xiaoxiang Guan 1,2,3*
}

\begin{abstract}
Background: Increasing evidence has indicated an important role for estrogen receptor beta 1 (ERß1) in breast cancer. However, the role of ERß1 in the metastasis of androgen receptor (AR)-positive triple-negative breast cancer (TNBC) and the underlying mechanisms are still unknown.

Methods: Stable ERß1-expressing TNBC cell lines were generated for this study. We detected the abilities of cell migration and invasion by wound-healing and transwell assays and the expression of E-cadherin and $\mathrm{N}$-cadherin by quantitative RT-PCR (qRT-PCR) and western blotting assays in TNBC cell lines. Chromatin immunoprecipitation (ChIP) analysis was performed to assess the effect of AR on ERß1 promoter. Tumor metastasis was evaluated in vivo using a lung metastasis mouse model. Lastly, immunohistochemical expression of ER $\beta 1$ in TNBC tissues was analyzed and correlated with clinicopathological features.
\end{abstract}

Results: ERB1 suppressed the invasion and migration abilities of AR-positive TNBC cells and induced the downregulation of ZEB1. ZEB1 overexpression abrogated the increase in E-cadherin expression and the decrease in $\mathrm{N}$-cadherin expression modulated by ERß1. A lung metastasis mouse model showed that the incidence of metastasis was lower in ER $\beta 1$-expressing TNBC cells. Further, AR activation increased the anti-metastatic effect of ER $\beta 1$ in AR-positive TNBC cells, which accelerated ER $\beta 1$ transcription by functioning as a transcription factor that bound to the promoter of ERß1. No significant change was observed in AR expression induced by ER $\beta 1$. Immunohistochemistry $(I H C)$ analysis of TNBC clinical samples showed that ERB1 and AR were positive in 31. $7 \%$ and $23.2 \%$ of samples, respectively. ERB1 expression was negatively correlated with ZEB1 expression and lymph node metastasis, and positively correlated with the expression of AR and E-cadherin.

Conclusion: Our findings suggested a potential role of ER $\beta 1$ in metastasis of AR-positive TNBC and provided novel insights into the mechanism of action of ERß1 and the possible relationship between ERß1 and AR.

Keywords: ERß1, AR, ZEB1, Triple-negative breast cancer

\section{Background}

TNBC is a special subgroup of breast cancer characterized by lack of estrogen receptor alpha $(E R \alpha)$, progesterone receptor (PR) and human epidermal growth factor receptor 2 (HER2), and it accounts for approximately 15 to $20 \%$ of breast cancer patients [1]. TNBC is more aggressive than other breast cancer subtypes, and

\footnotetext{
* Correspondence: xguan@nju.edu.cn

'Department of Medical Oncology, Jinling Hospital, Southern Medical University, Guangzhou 510515, China

${ }^{2}$ Department of Medical Oncology, Jinling Hospital, Medical School of Nanjing University, Nanjing 210002, China

Full list of author information is available at the end of the article
}

it is more likely to metastasize at an early stage [2, 3]. TNBC remains the hardest breast cancer subtype to treat because it is a highly heterogeneous disease and lacks effective targets for therapy [2]. Thus, it is important to classify effective TNBC subtypes and identify novel therapeutic targets. Approximately $12-36 \%$ TNBC patients are AR-positive [4-6]. As a newly emerging biomarker, the role of the AR pathway has been recently investigated in TNBC. Conflicting results have been reported in preclinical studies, and their impact on clinical outcome is still debated. McGhan LJ et al. declared that AR-positive TNBC has a higher propensity for lymph 
node metastases [7]. However, it has also been shown that there is not any significant correlation between the sites of distal metastasis and AR status in recurrent specimens [8]. Lisa MS et al. indicated that decreased AR expression is associated with distant metastases in patients with AR-expressing TNBC [9]. AR positivity has also been reported to be associated with lower risk of disease recurrence in TNBC [10].

The downregulation of ER $\beta 1$, the fully functional $E R \beta$ isoform (also known as wild-type ER $\beta$ ), promotes epithelial-mesenchymal transition (EMT) in prostate cancer cells [11]. ER $\beta 1$ has also been investigated in breast cancer with contradictory results. Some studies have shown that ER $\beta 1$ inhibits the growth and decreases the invasiveness of breast cancer cells, and it predicts a favorable survival for ER $\alpha$-negative breast cancer [12-14]. Whereas estrogen receptor beta 2 (ER $\beta 2)$, one of the splice variants of ER $\beta$, has been reported to be associated with poor prognosis in ER $\alpha$-negative breast cancer [15]. Other studies have indicated that ER $\beta 1$ has no prognostic significance in breast cancer $[16,17]$. Among TNBC patients, approximately $30 \%$ show overexpression of ER $\beta 1$ $[12,18]$. Patients with TNBC harboring ER $\beta 1$-positive tumors treated with adjuvant tamoxifen have significantly better survival [19]. However, little is known about the functions and underlying mechanisms of ER $\beta 1$ in metastasis in AR-positive TNBC. In this study, stable ER $\beta 1$ expressing cells were generated using two AR-positive TNBC cell lines. ER $\beta 1$ suppressed the invasion and migration abilities of AR-positive TNBC cells by inducing the downregulation of ZEB1. This study also investigated the potential regulatory relationship between $E R \beta 1$ and $A R$ as well as the association of ER $\beta 1$ with AR and ZEB1 in TNBC clinical samples.

\section{Methods}

\section{Clinical specimens}

Eighty two TNBC tissue samples were collected from patients who underwent tumor resection in The First Affiliated Hospital of Wenzhou Medical University from April 2005 to March 2014. The use of clinical tissues for this study was approved by the Jinling Hospital's Ethics Committees and conducted in accordance with the Helsinki Declaration. All patients gave their informed consent prior to inclusion in the study.

\section{Cell lines, Animals and Reagents}

Human TNBC cell lines, MDA-MB-231 cells and Hs578T cells were obtained from the American Type Culture Collection (ATCC, Manassas, VA, USA) and cultured in RPMI-1640 or Dulbecco's Modified Eagle Medium supplemented with $10 \%$ fetal bovine serum (FBS) at $37^{\circ} \mathrm{C}$ in $5 \% \mathrm{CO}_{2}$. For the ligand experiments, cells were maintained in phenol red-free media containing 5\% dextran-coated charcoal (DCC)-treated FBS. BALB/c athymic nude mice (female, 6 weeks old) were purchased from the Department of Comparative Medicine, Jinling Hospital (Nanjing, China) and maintained in a pathogenfree facility. $5 \alpha$-Dihydrotestosterone (DHT) was purchased from Sigma-Aldrich (St. Louis, USA).

\section{RNA extraction and qRT-PCR}

Total RNA was extracted from cultured cells using TRIzol (Invitrogen, USA). For qRT-PCR analysis, cDNA was synthesized using the PrimeScript ${ }^{\mathrm{TM}}$ RT Master Mix (Perfect Real Time) Kit (RR036A, Takara, China), and PCR was performed using the Power SYBR Green PCR Master Mix (Life Technology, USA). The primer sequences were as follows: ER $\beta 1$ forward 5'- CGATGC TTTGGTTTGGGTGAT-3' and reverse 5'-GCCCTCTT TGCTTTTACTGTC-3'; AR forward 5'-CCTGGCTTCC GCAACTTACAC-3' and reverse 5'-GGACTTGTGCAT GCGGTACTCA-3'; E-cadherin forward 5'-TGAAGGT GACAGAGCCTCTGGAT-3' and reverse 5'-TGGGTGA ATTCGGGCTTGTT-3'; N-cadherin forward 5'-CACTG CTCAGGACCCAGAT-3' and reverse 5'-TAAGCCGAG TGATGGTCC-3'; ZEB1 forward 5'-GCCAATAAGCA AACGATTCTG-3' and reverse 5'-TTTGGCTGGATCA CTTTCAAG-3'; Snail forward 5'-CACTATGCCGCG CTCTTTC-3' and reverse 5'-GGTCGTAGGGCTGCT GGAA-3'; Twist forward 5'-AGTCCGCAGTCTTACGA GGA-3' and reverse 5'-GCCAGCTTGAGGGTCTGA AT-3'; and GAPDH forward 5'AAATCAAGTGGGGC GATGCTG-3' and reverse 5'-GCAGAGATGATGACC CTTTTG-3'. The $2^{-\Delta \Delta C t}$ method was used to determine the relative mRNA expression.

\section{Plasmids and Transfection}

The human full-length cDNA of ER $\beta 1$ and ZEB1 were cloned into the pFLAG-CMV expression vector (Sigma) and verified by sequence analysis before transfection, respectively. The MDA-MB-231 and Hs578T cells were transfected with an empty vector or pFLAG-CMV-ER $\beta 1$ by Lipofectamine 2000 (Invitrogen, USA) following selection by $1 \mathrm{mg} / \mathrm{ml} \mathrm{G} 418$ (Gibco). AR shRNA (shAR) and scrambled shRNA control (shNC) were cloned into the pGpU6/GFP/Neo vector purchased from GenePharma (Shanghai, China) and transfected into cells according to the manufacturer's protocol. The shRNA sequences were as follows: shAR, 5'-CACCAATGTCAACTCCAGGAT-3', and shNC, 5'-AGTGCACGTGCATGTCCTA-3'.

\section{Wound-healing and Transwell assays}

Cells were seeded in 6-well plates and incubated to generate confluent cultures. Wounds were scratched in the cell monolayer using a $200 \mu \mathrm{l}$ sterile pipette 
tip, and cells were rinsed with PBS. The migration of the cells at the edge of the scratch was photographed at 0 and $24 \mathrm{~h}$. The invasion ability of cells was determined using 24-well transwell chambers (Costar, USA) coated with matrigel (BD Biosciences, San Jose, CA). After transfection, approximately $1 \times 10^{5}$ cells/ $200 \mu \mathrm{l}$ were resuspended in medium without serum and plated in the top chamber of each transwell, and $800 \mu \mathrm{l}$ of medium supplemented with 10\% FBS was injected into the lower chamber. After $24 \mathrm{~h}$ incubation, the inserts were fixed with $100 \%$ methanol, subsequently stained with crystal violet and photographed under a microscope.

\section{Western blot and Immunofluorescence}

Cells lysates were resolved by SDS-PAGE electrophoresis (30 $\mathrm{\mu g} / \mathrm{sample})$ and electro-transferred onto polyvinylidene fluoride (PVDF) membranes. After incubation in blocking buffer, the membranes were probed overnight at $4{ }^{\circ} \mathrm{C}$ with the following primary antibodies: GAPDH (CST), 1:5000; ER $\beta 1(s c-6822$ ) (Santa Cruz), 1:200; AR (D6F11) (CST), 1:2000; E-cadherin(24E10) (CST),1:1000; $\mathrm{N}$-cadherin(D4R1H) (CST), 1:1000; ZEB1(D80D3) (CST), 1:1000; Snail (C15D3) (CST), 1:1000; and Twist (ab50581) (Abcam), 1:500. The subsequent steps were performed as previously described [20].

Cells were fixed with $3 \%$ paraformaldehyde for $10 \mathrm{~min}$, permeabilized with $0.1 \%$ SDS solution in PBS for $10 \mathrm{~min}$ and then blocked for $20 \mathrm{~min}$. Fixed cells were stained with primary antibodies and then with a secondary antibody coupled to Dylight 649 for $30 \mathrm{~min}$. Cell nuclei were stained with Dapi-Fluoromount-G for $15 \mathrm{~min}$. The expression was defined as follows: -, no immunofluorescence; \pm , weak immunofluorescence; + , moderate immunofluorescence; ++ , strong immunofluorescence; and +++ , very strong immunofluorescence. The samples with scores ++ or +++ were defined as high expression, and the remaining samples were defined as low expression.

\section{Immunohistochemistry}

Following deparaffinization, sections were rehydrated and subjected to antigen retrieval using citrate buffer (BioGenex, USA). The slides were incubated with primary antibodies, including ER $\beta 1$ (ab27720) (Abcam) and other antibodies as described in the previous section, at $4{ }^{\circ} \mathrm{C}$ overnight. The following steps were performed as previously described [20]. The cut-offs for positivity at $1 \%$ and $20 \%$ were defined as AR-positive and ER $\beta 1$ positive, respectively $[9,21]$. The percentages of positive cells and staining intensities were scored as previously described [20]. IHC scoring was performed without prior knowledge of the clinical response.

\section{Chromatin immunoprecipitation}

The cells were treated with $1 \%$ formaldehyde for $8 \mathrm{~min}$ to crosslink histones to DNA. After washing with cold PBS, the cell pellets were resuspended in lysis buffer and sonicated for $8 \mathrm{~s} 7$ times. The lysate was divided into three fractions, which were incubated with IgG antibody as a negative control, RNA polymerase II antibody as a positive control, or AR antibody (ab74272) (Abcam), at $4{ }^{\circ} \mathrm{C}$ overnight. To collect the immunoprecipitated complexes, protein A-Sepharose beads (Pharmacia Biotech) were added and incubated for $1 \mathrm{~h}$ at $4{ }^{\circ} \mathrm{C}$. After washing, the beads were treated with RNase $(50 \mu \mathrm{g} / \mathrm{ml})$ for $30 \mathrm{~min}$ at $37^{\circ} \mathrm{C}$ and then proteinase $\mathrm{K}$ overnight. The crosslinks were reversed by heating the sample at $65{ }^{\circ} \mathrm{C}$ for $1.5 \mathrm{~h}$. DNA was extracted by the phenol/chloroform method, ethanol-precipitated, and resuspended, and it was then used for PCR, the primer sequences were shown in Table 1.

\section{Tumor metastasis model}

All animal experiments were conducted in accordance with the Guide for Care and Use of Laboratory Animal, and all experimental protocols were approved by the Animal Ethics Committee. The control and ER $\beta 1$ expressing MDA-MB-231 and Hs578T cells $\left(1 \times 10^{7}\right.$ cells/ $\mathrm{ml}, 100 \mathrm{ul} / \mathrm{mouse}$ ) were injected into 6-week-old BALB/c female nude mice via the tail vein to establish a tumor lung metastasis model. The lungs of mice were removed on the eighth week after injection.

Table 1 Primers for ER $\beta 1$ promoter sequence in ChIP assay

ERß1-F1: 5'-TCATAAACTTTGTGGCTAAAACAG-3' ERß1-R1: 5'-AGAGAAGAGGGAGGCAAG-3'

ERß1-F2: 5'-CTCTATTITTAAGGGTGCTTGTG-3' ERß1-R2: 5'-GCTATTTCTTTTATTTTGTGGCAC-3'

ERß1-F3: 5'-CTCAGCAAGGCAAATTTACTCTTTC-3' ERß1-R3: 5'-CAAGACAGCCAAGAAATCACC-3'

ERß1-F4: 5'-TGTCTTGCCTGAGCACAGCA-3' ERß1-R4: 5'-CGTGCCATTACACTCCAGC-3'

ERß1-F5: 5'- ATCTTGGCTTACTGCAACCTC-3' ERß1-R5: 5'-CCACCGTTAGTAATATTGTAAATGTC-3'

ERß1-F6: 5'-GCATTGTTCATTATTGCCGGAAAC-3' ERß1-R6: 5'-GTATTTTTAGTAGAGACGGGGTTTC-3'

ERß1-F7: 5'-CAAAATTAGCCAGGCGTGG-3' ERß1-R7: 5'-TCCTTACAAGCCCATTGCTTTC-3'

ERß1-F8: 5'-GAACTTGGTTCTTGTTGAACATCC-3' ERß1-R8: 5'-ATCTCAGCCTGCCACAC-3'

ERß1-F9: 5'-ATCTGCCTCCTTGTTCCCG-3' ERß1-R9: 5'-GCCCTTACTTCCTTTTCCCTTAAG-3'

ERß1-F10: 5'-CCTTAAGGGAAAAGGAAGTAAGGGC-3' ERß1-R10: 5'-CCTCTCCCTGATTGGCTCGAAT-3' 


\section{Statistical analysis}

Data from at least three independent experiments are presented as the means \pm standard error of the mean. Differences between groups were calculated by Student's t-test or one-way analysis of variance using the SPSS 19.0 software package (SPSS Inc.). The association in TNBC tissues was explored by the Spearman rank correlation. $P<0.05$ was considered to indicate a statistically significant difference.

\section{Results}

ER $\beta 1$ suppresses cell migration and invasion of AR-positive TNBC cells

Previous studies had shown an association of ER $\beta 1$ expression with tumor metastasis and the suppression of factors known to be involved in bone metastasis in prostate cancer [22]. We hypothesized that ER $\beta 1$ may regulate metastasis in TNBC. To explore the functions of ER $\beta 1$ on tumor metastasis in AR-positive TNBC, we transfected two AR-positive TNBC cell lines, MDA-MB231 and Hs578T, with the empty vector or the ER $\beta 1$ expression vector. Eight weeks later, stable ER $\beta 1$ expressing cell lines were obtained and confirmed by Western blot analysis and qRT-PCR (Fig. 1a and b). Wound-healing and transwell assays were then performed to evaluate the migration and invasion of these cells. The results showed that ER $\beta 1$ repressed the migration and invasion of two cell lines, MDA-MB-231ER $\beta 1$ and Hs578T-ER $\beta 1$, when compared to the control $(P<0.05)$ (Fig. 1c and d). Our results suggested that ER $\beta 1$ inhibits the migration and invasion abilities of ARpositive TNBC cells.

\section{ER $\beta 1$ suppresses metastasis of AR-positive TNBC by inhibiting ZEB1}

We next investigated the underlying mechanisms by which ER $\beta 1$ suppresses the metastasis of AR-positive TNBC. As shown in Fig. 2a, compared with the control cells, ER $\beta 1$ upregulated E-cadherin epithelial marker expression (1.75-fold and 1.60-fold increase) and downregulated N-cadherin mesenchymal marker expression (56\% and $32 \%$ decrease) in MDA-MB-231-ER $\beta 1$ and Hs578TER $\beta 1$ cells, respectively. The results of qRT-PCR revealed that ER $\beta 1$ was also positively associated with E-cadherin mRNA and inversely associated with $\mathrm{N}$-cadherin mRNA (Fig. 2b). Moreover, the results of immunofluorescence showed higher expression of E-cadherin and lower expression of N-cadherin on the cell surface of ER $\beta 1$-expressing cells compared to control cells (Fig. 2c), suggesting that ER $\beta 1$ promoted cell-cell adhesion by regulating the expression of E-cadherin and N-cadherin. Several transcription factors, such as Snail, Twist and ZEB1, had been reported to promote EMT in multiple tumors, including breast cancer [23, 24]. For example, BCL6 induced EMT by promoting the ZEB1-mediated transcription repression of E-cadherin in breast cancer cells. Therefore, we examined if the inhibition of these factors was involved in the regulation of ER $\beta 1$-induced E-cadherin and $\mathrm{N}$-cadherin expression. Only ZEB1 expression was reduced in both ER $\beta 1$-expressing cell lines compared to control cells (Fig. 2d). In addition, qRT-PCR revealed that ER $\beta 1$ inhibited ZEB1 expression at the transcriptional level (Fig. 2e). ZEB1 overexpression abrogated the increase of E-cadherin expression and the decrease of $\mathrm{N}$-cadherin expression caused by ER $\beta 1$ overexpression (Fig. 2f). Taken together, these data showed that ER $\beta 1$ regulates E-cadherin and $\mathrm{N}$-cadherin expression through inhibiting ZEB1.

\section{ER $\beta 1$ inhibits metastasis of AR-positive TNBC cells in vivo}

To further investigate the anti-metastatic effect of ER $\beta 1$ in vivo, we established a lung metastasis mouse model using control TNBC cells and ER $\beta 1$-expressing TNBC cells. Lung metastasis was determined by comprehensive analysis of macroscopical observation and HE staining of lung tissue sections. The results showed that there was higher occurrence of lung metastasis (4/8 in MDA-MB-231 and 3/8 in Hs578T) in the control cells and a lower occurrence of lung metastasis (1/8 in MDA-MB-231-ER $\beta 1$ and 1/8 in Hs578TER $\beta 1$ ) in ER $\beta 1$-expressing cells (Fig. 3a and b). Fig. 3c showed the representative HE staining of lung tissues from mice treated with control or ER $\beta 1$-expressing MDA-MB231 and Hs578T cells. Our results showed that ER $\beta 1$ inhibits metastasis of AR-positive TNBC cells in vivo.

\section{AR promotes the anti-metastatic effect of ER $\beta 1$}

AR is expressed in both MDA-MB-231 and Hs578T TNBC cell lines. It has been reported that AR expression correlates with metastases in TNBC. We further examined if $\mathrm{AR}$ is involved in the regulation of ER $\beta 1$-mediated metastasis inhibition in TNBC cells. Wound-healing and transwell assays showed that AR activation by DHT inhibited cell migration and invasion ability in both MDA-MB231-ER $\beta 1$ and Hs578T-ER $\beta 1$ cells compared to control cells (Fig. 4a and b). Moreover, ZEB1 protein was downregulated after AR activation, which was accompanied by upregulated E-cadherin and downregulated N-cadherin, in both ERß1-expressing cell lines (Fig. 4c). As mentioned above, ZEB1 expression responded to the modulation of ER $\beta 1$. We measured the expression of ER $\beta 1$ after AR activation and found that activated AR increased ER $\beta 1$ protein and mRNA expression levels (Fig. 4c and d). These data suggested that AR activation enhances ER $\beta 1$ expression, which improves the suppressive effect of ER $\beta 1$ mediated metastasis in ER $\beta 1$-expressing TNBC cells.

\section{AR acts as a transcription factor that binds to the promoter of ER $\beta 1$}

We next investigated the possible mechanisms by which AR regulated ER $\beta 1$ expression. First, we detected the 
$\mathbf{a}$

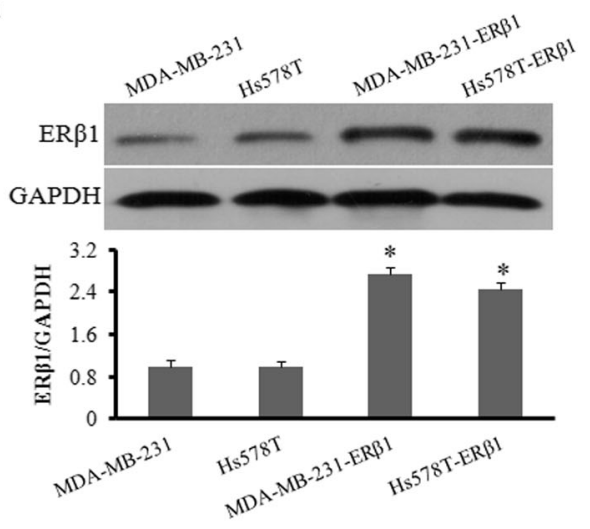

c
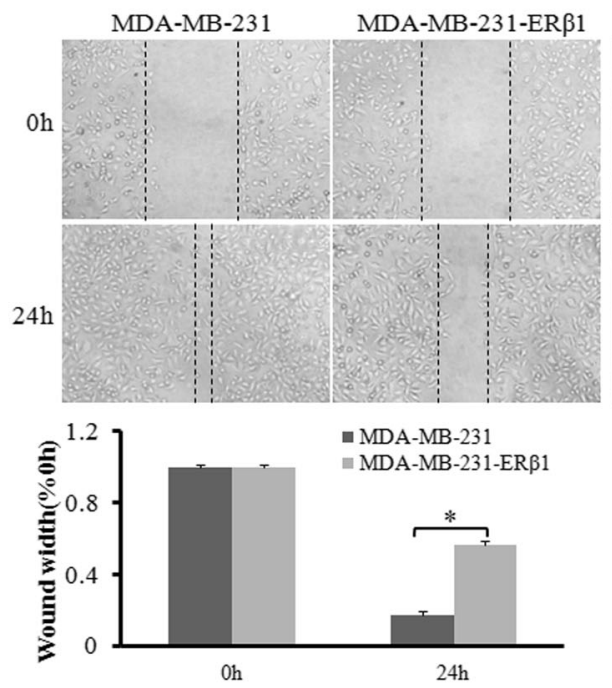

d
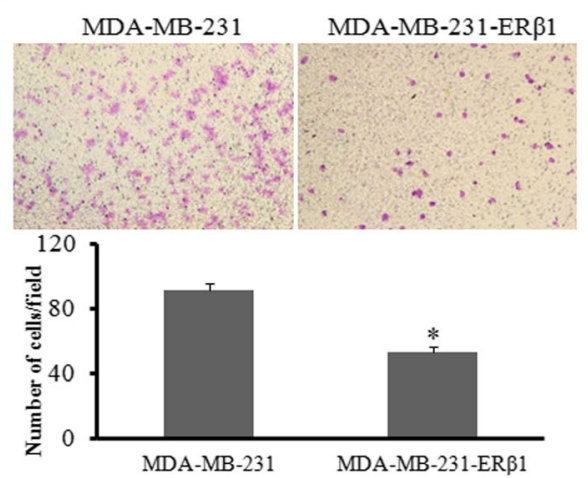

b

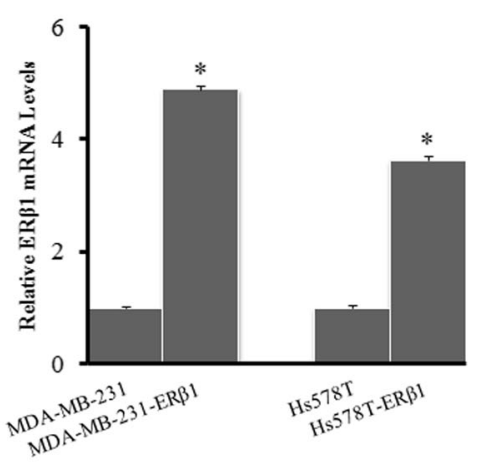

Hs578T
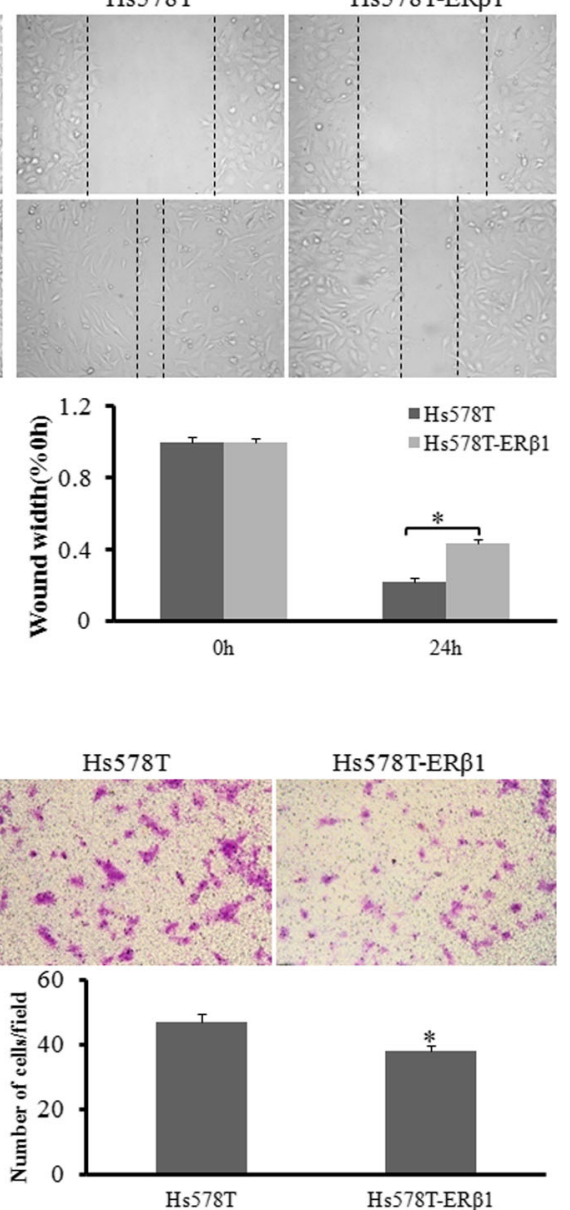

Fig. 1 ER 1 suppresses cell migration and invasion of AR-positive TNBC cells. $\mathbf{a}$, $\mathbf{b}$ Western blot analysis and qRT-PCR of ER 1 protein and mRNA expression in the control and stable ERB1-transfected cell lines. c Representative images of wound-healing assays in the control and ERß1-expressing cell lines. The widths of injury lines made in cells were examined at 0 and $24 \mathrm{~h}$. Wound-healing migration is represented by the widths of injury lines. d Representative results of transwell assays showing the effect of ERB1 overexpression on the invasion ability in control and ERß1-expressing MDA-MB231 and Hs578T cells. ${ }^{*} p<0.05$

expression of ER $\beta 1$ after AR knockdown by shAR in the presence of DHT. AR knockdown led to a decrease in the expression of ER $\beta 1$ protein and mRNA compared to the negative control (Fig. 5a and b), which indicated that DHT caused the above changes through activation of the AR signaling pathway. It is well known that AR, as a 
a
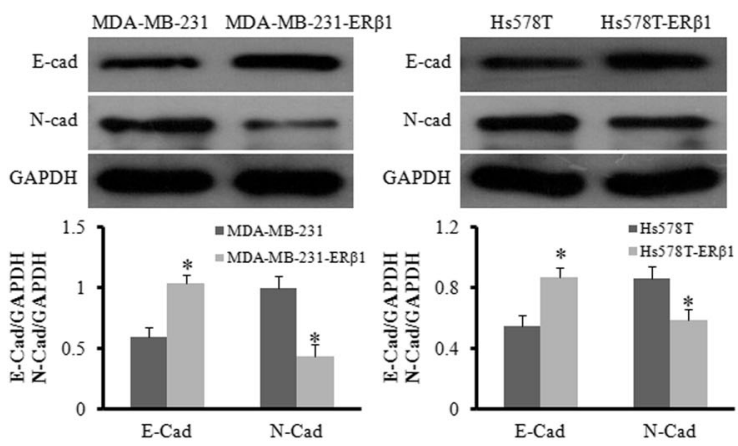

c

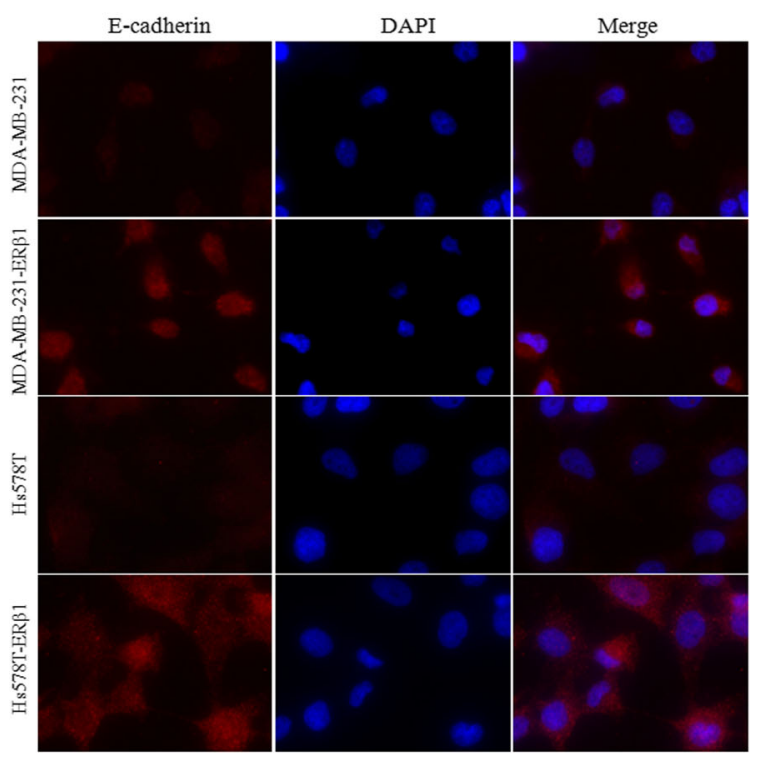

d
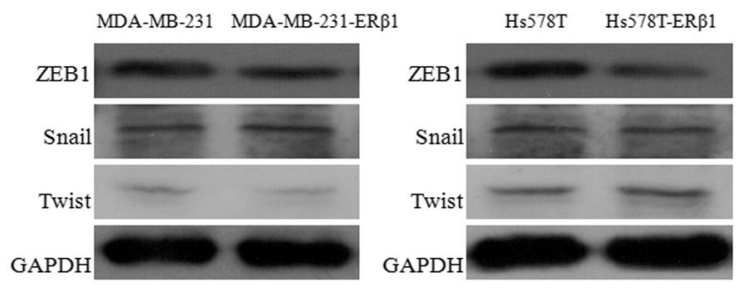

\section{f}
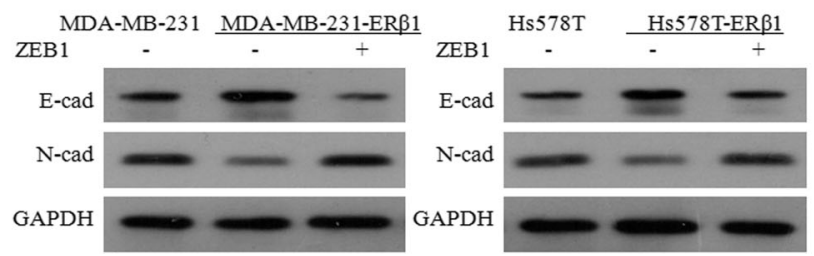

b
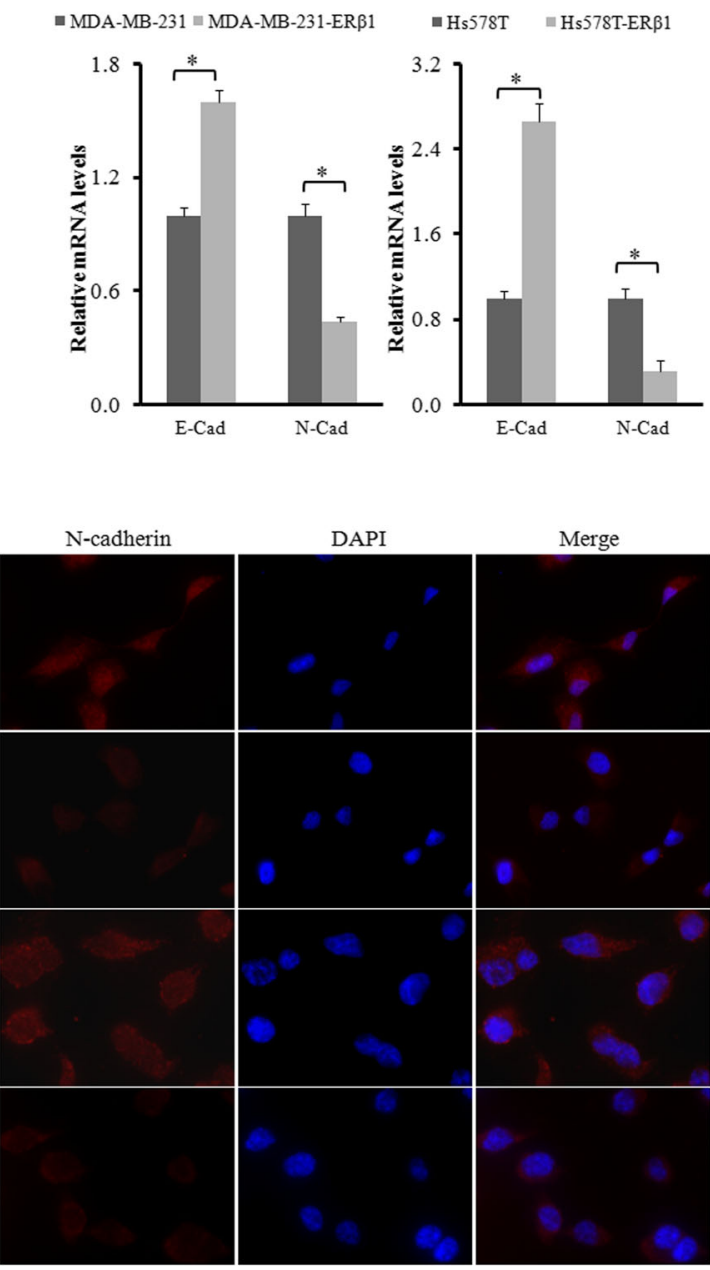

e
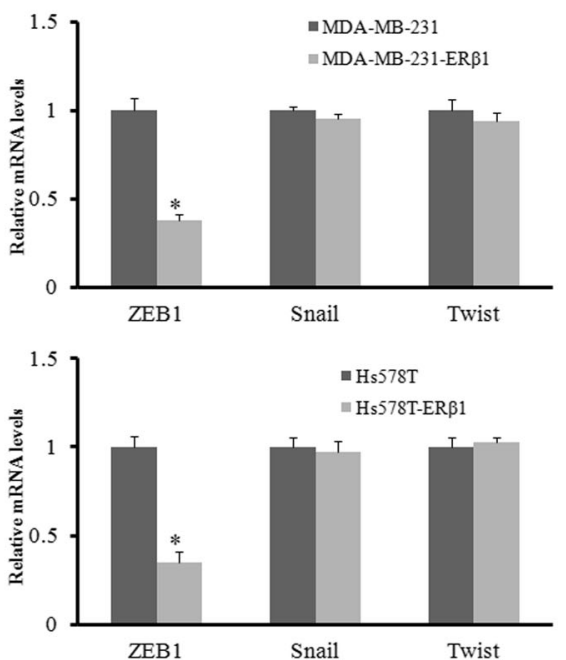

Fig. 2 (See legend on next page.) 
(See figure on previous page.)

Fig. 2 ERB1 suppresses metastasis of AR-positive TNBC by inhibiting ZEB1. a Western blot analysis of E-cadherin and N-cadherin protein in control and ERß1-expressing cells. GAPDH expression was used as the loading control. $\mathbf{b}$ qRT-PCR detection of E-cadherin and N-cadherin mRNA expression in control and ERß1-expressing MDA-MB-231 and Hs578T cells. c Fluorescent microscopy analysis of the expression of E-cadherin and N-cadherin by immunofluorescence. The red signal represents E-cadherin or N-cadherin protein, and the blue signal represents the nuclear DNA staining by DAPI. $\mathbf{d}$, e Western blot and qRT-PCR analyses of ZEB1, Snail and Twist in the control and ERß1-expressing cells. $\mathbf{f}$ Western blot of E-cadherin and N-cadherin expression after transfection with ZEB1 or empty vector in the control and ERß1-expressing MDA-MB-231 and Hs578T cells. ${ }^{*} p<0.05$

transcription factor, regulates the expression of many genes in many different cellular processes $[25,26]$. Because we showed that ER $\beta 1$ expression was regulated by activated AR at both protein and mRNA levels, we hypothesized that AR functioned as a transcription factor that directly bound to the promoter region of ER $\beta 1$. To better determine if AR binds to the promoter of ER $\beta 1$, a ChIP assay was performed using ER $\beta 1$-expressing MDA-
MB-231 cells exposed or not exposed to DHT. The results showed that AR, as a transcription factor, directly bound to the promoter of ER $\beta 1$ and that the recruitment of AR to the promoter of ER $\beta 1$ was increased with DHT treatment (Fig. 5c and d). Furthermore, no difference in AR protein and mRNA expression was observed between the control and ER $\beta 1$-expressing TNBC cells (Fig. 5e and f). Our results suggested that activated AR

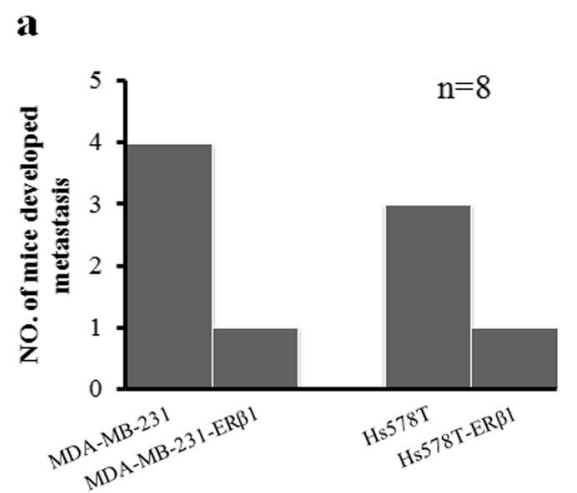

\section{b}

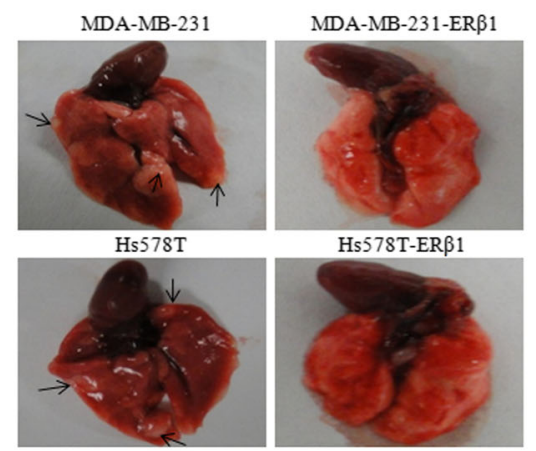

c

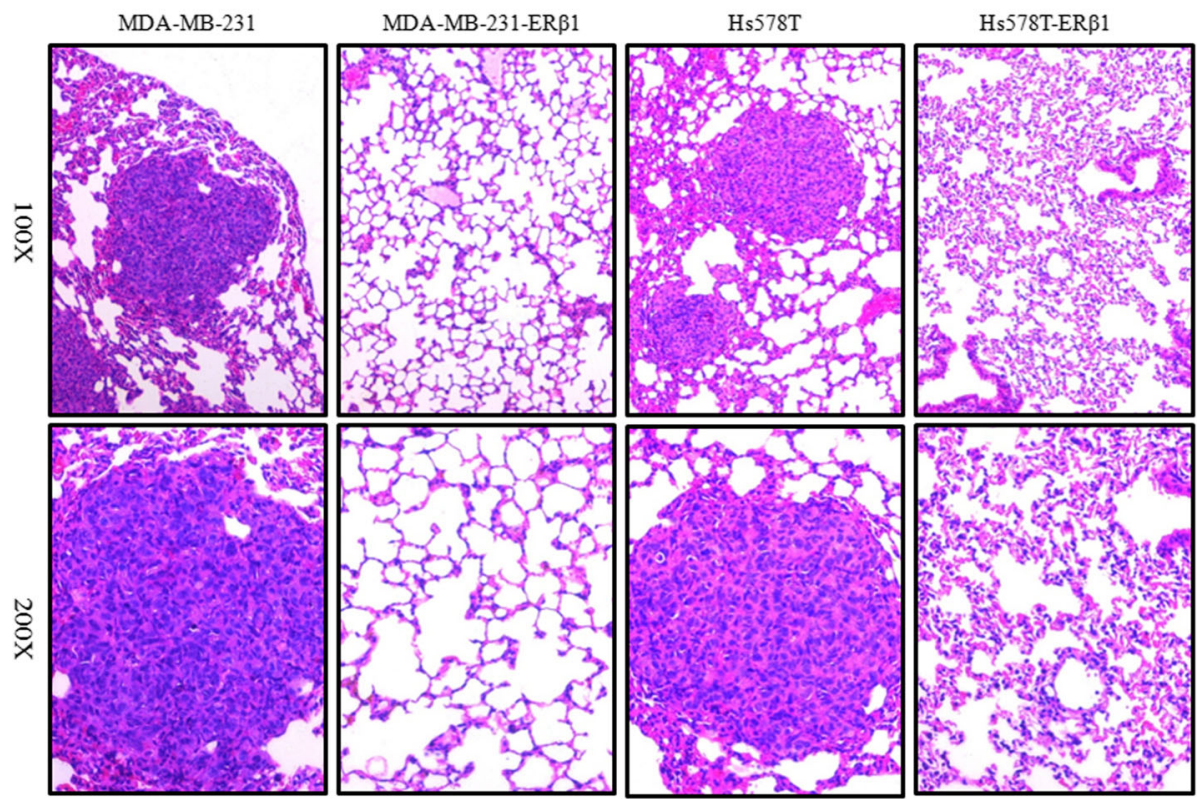

Fig. 3 ER $\beta 1$ inhibits metastasis of AR-positive TNBC cells in vivo. a Lung metastasis rate of mouse models in the control and ER $\beta 1$-expressing groups $(n=8)$. $\mathbf{b}$ Representative images of lung metastasis in mouse models injected with control and ER 31 -expressing MDA-MB-231 and Hs578T cells. c Representative HE staining of lung sections from the control or ER 1 1-expressing groups 


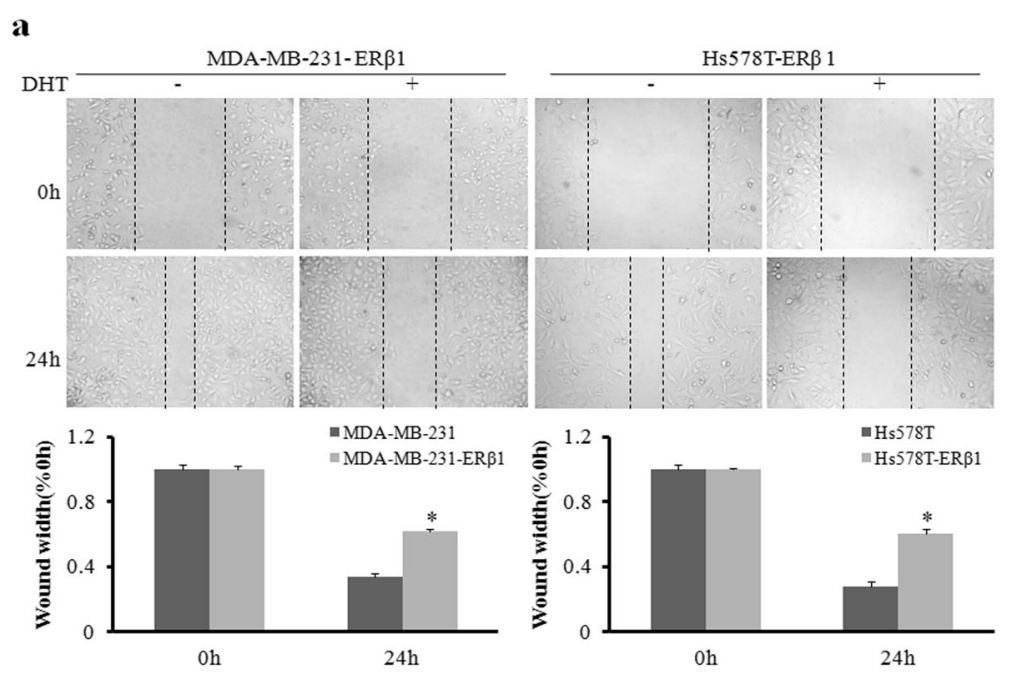

b
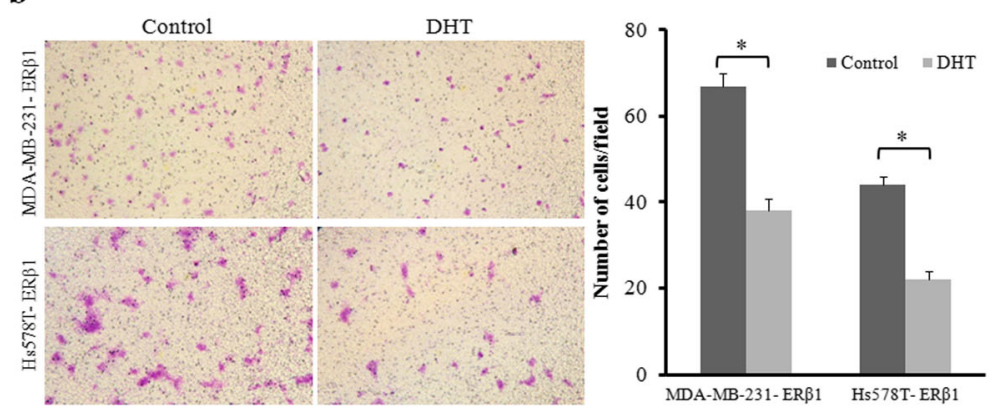

c

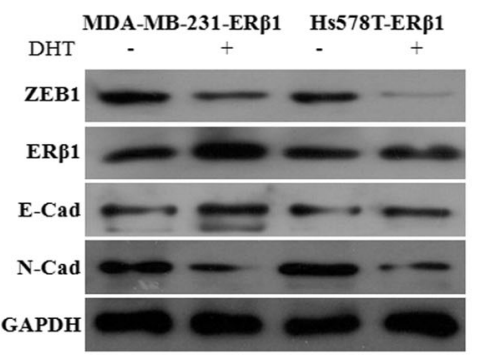

d

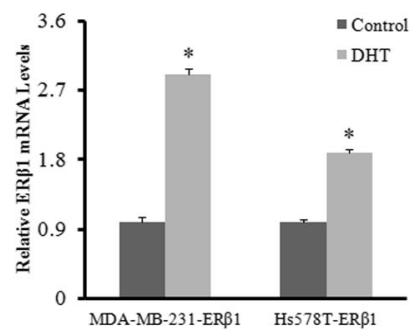

Fig. 4 AR promotes the anti-metastatic effect of ERß1. a Wound-healing assay for the cell migration of ERß1-expressing MDA-MB-231 and Hs578T cells with or without DHT (10nM) treatment. The percentage of wound healing was calculated. $\mathbf{b}$ Representative images of transwell assays for the invasion of MDA-MB-231 and Hs578T cells treated with or without DHT. c Western blot analysis of ZEB1, ERß1, E-cadherin and N-cadherin protein levels in ERß1-expressing MDA-MB-231 and Hs578T cells after treatment with or without DHT. $\mathbf{d}$ qRT-PCR detection of ER 31 mRNA in ERß1-expressing MDA-MB-231 and Hs578T cells with or without DHT treatment. ${ }^{*} p<0.05$

promotes the expression of ER $\beta 1$ by functioning as a transcription factor that directly binds to the promoter of ER $\beta 1$.

\section{Relationships of ERß1 with clinicopathological factors in TNBC}

We next examined the correlation of ER $\beta 1$ with AR, ZEB1, E-cadherin and clinical characteristics in 82 TNBC samples. The protein levels of ER $\beta 1$, AR, ZEB1, and E-cadherin were determined by IHC (Fig. 6a and b). Our results showed that ER $\beta 1$ and AR were overexpressed in $31.7 \%(26 / 82)$ and $23.2 \%(19 / 82)$ of the TNBC clinical samples, respectively (Table 2). There was a negative correlation between ER $\beta 1$ and ZEB1 $(r=-0.330$, $P=0.003)$ and a positive correlation between ER $\beta 1$ and Ecadherin $(r=0.391, P<0.001)$ (Table 2). Moreover, ER $\beta 1$ expression was negatively correlated with lymph node metastasis $(\mathrm{r}=-0.368, P=0.001)$, and positively correlated 

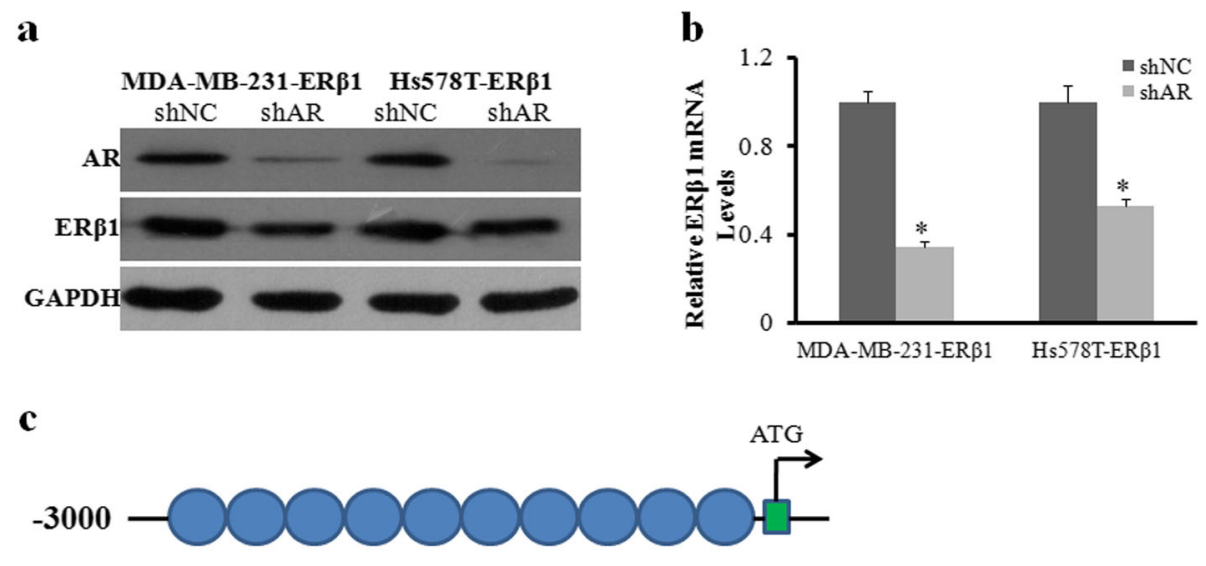

$\begin{array}{lllllllllllllll}\text { P1 } & \text { P2 } & \text { P3 } & \text { P4 } & \text { P5 } & \text { P6 } & \text { P7 } & \text { P8 } & \text { P9 } & \text { P10 }\end{array}$

d

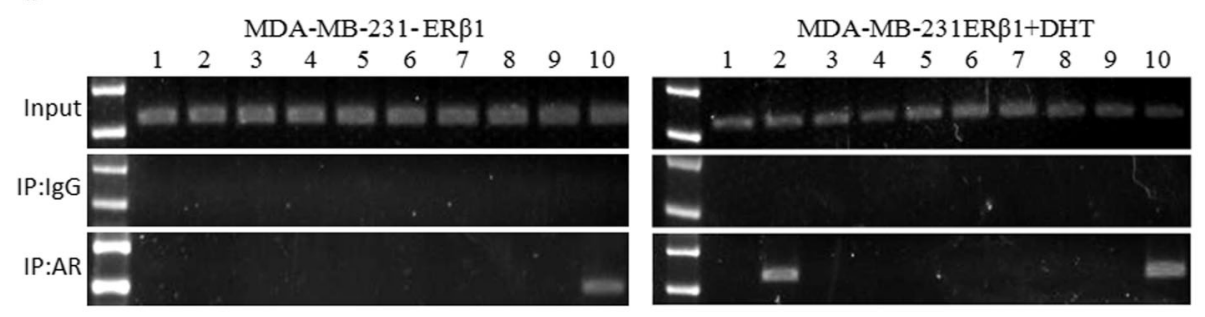

e

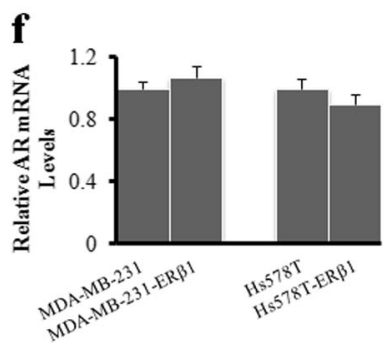

Fig. 5 AR acts as a transcription factor that binds to the promoter of ER $\beta 1$. $\mathbf{a}$, $\mathbf{b}$ Western blot and $q R T-P C R$ analyses of ER $\beta 1$ protein and $m R N A$ with or without AR knockdown in ERß1-expressing MDA-MB-231 and Hs578T cells in the presence of DHT. c Primers used for PCR in the ChIP assay. $\mathbf{d}$ The gel electrophoresis of ChIP assay showed a binding site located in primer 10 without DHT treatment and two binding sites located in primers 2 and 10 with DHT treatment in ERB1-expressing MDA-MB-231 cells. e, $\mathbf{f}$ Western blot and qRT-PCR analyses of AR protein and mRNA in the control and ERß1-expressing cells. ${ }^{*} p<0.05$

with the expression of AR $(r=0.309, P=0.005)$. There was no association of ER $\beta 1$ expression with age and tumor size. Besides, the 82 TNBC clinical samples were divided into ER $\beta 1$-negative or ER $\beta 1$-positive groups based on the level of ER $\beta 1$. The ER $\beta 1$-positive group had higher percentage of E-cadherin-positive, ZEB1-negative and ARpositive samples (Fig. 6c).

\section{Discussion}

Numerous findings have shown that TNBC is a heterogeneous disease not only on the clinical level but also on the molecular level [2]. TNBC is associated with a significantly higher probability of relapse and metastasis compared with other breast cancer subtypes [27]. The molecular complexity of TNBC has led to the subclassification into different subgroups, which is necessary to better identify molecular-based therapies [28, 29]. For example, the AR signaling pathway has long been thought to play a critical role in TNBC and to likely be relevant to tumor metastasis. According to AR status, TNBC is divided into two subtypes as follows: AR-positive TNBC or Quadruple Negative breast cancer $[4,30]$. Interestingly, it also has been reported that ER $\beta 1$ is involved in the regulation of metastasis in breast cancer. For example, some studies have shown that ER $\beta 1$-positive TNBC patients tend to be less likely to develop lymphatic metastasis [12]. ER $\beta 1$ represses EMT by destabilizing EGFR in basal-like breast cancer [31]. However, other studies have indicated 
a

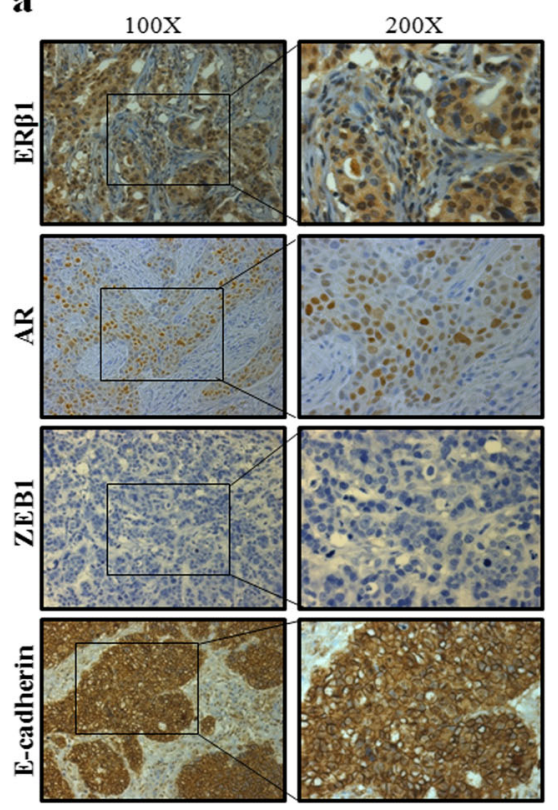

b

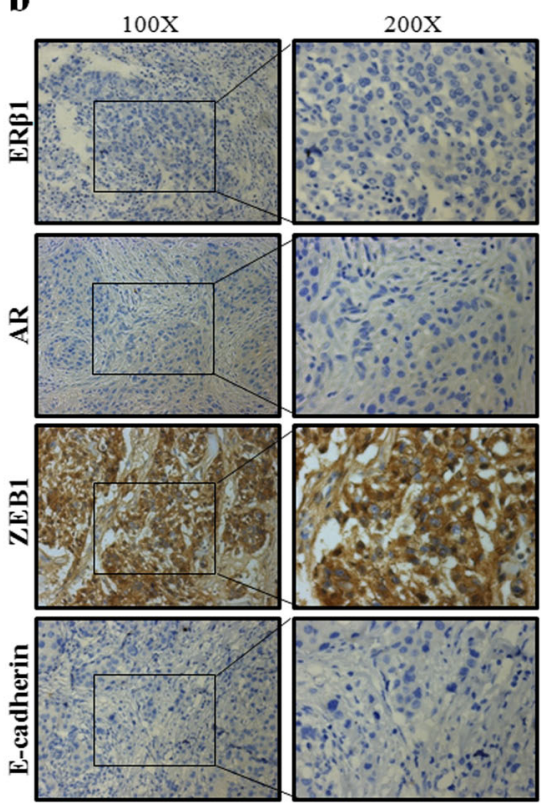

AR
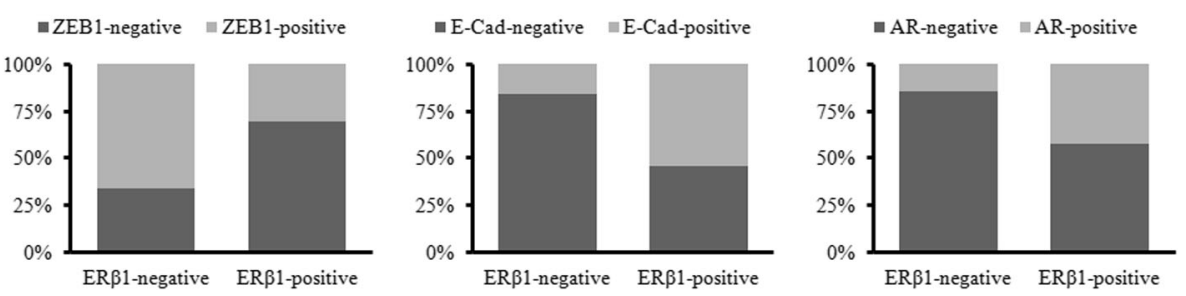

Fig. 6 Relationships of ERß1 with clinicopathological factors in TNBC. a, b Representative IHC staining of ERß1 high-, AR high-, ZEB1 low-, and E-cadherin high-expression (a) or ERB1 low-, AR low-, ZEB1 high-, and E-cadherin low-expression (b) in TNBC samples. $\mathbf{c}$ Expression ratio of $A R, Z E B 1$ and $E$-cadherin in ERß1-positive group or ERß1-negative group, respectively

that ER $\beta 1$ shows no correlation with metastasis and vascular invasion in breast cancer [14].

Here, we examined if ER $\beta 1$ influences migration and invasion of AR-positive TNBC cells and explored potential mechanisms. We found that ER $\beta 1$ inhibited migration and reduced the invasiveness of AR-positive TNBC cells. The expression of EMT markers, such as E-cadherin and $\mathrm{N}$-cadherin, has been reported to correlate with tumor metastasis [32, 33]. For example, PTK6 inhibition suppresses metastases of TNBC via Snail-dependent Ecadherin regulation [23]. We examined if ER $\beta 1$ inhibits invasion and migration by regulating EMT markers. ER $\beta 1$ was found to regulate the expression of E-cadherin by inhibiting its transcriptional repressor, ZEB1, in ARpositive TNBC cells. When control and ER $\beta 1$-expressing TNBC cells were injected into nude mice, the ER $\beta 1$ expressing cells were less likely to form lung metastases, suggesting that ER $\beta 1$ functions as an important antimetastasis factor.
Published studies focusing on the correlation between AR expression and tumor metastasis in TNBC remain controversial. Decreased AR expression has been reported to associate with the occurrence of distant metastasis [9]. Additionally, AR negativity has been associated with a shorter disease-free interval and overall survival (OS) compared to AR-positive TNBCs [34]. However, other studies have found that AR-positive TNBC is more common in older patients and has a higher propensity for lymph node metastases, and they have found that AR promotes cell migration in TNBC cells $[7,35]$. In our study, AR activation enhanced the inhibitory effect of ER $\beta 1$ on metastasis in ER $\beta 1$-expressing TNBC cells, and the protein and mRNA expression of ER $\beta 1$ was altered when AR was activated by DHT or knocked down by shAR. AR promoted the expression of ER $\beta 1$ by functioning as a transcription factor that directly bound to the promoter of ER $\beta 1$. Moreover, the expression of AR was not altered in control or 
Table 2 Patient characteristics and relationships between ER $\beta 1$ and clinicopathologic factors

\begin{tabular}{|c|c|c|c|c|c|}
\hline \multirow[t]{2}{*}{ Variables } & \multicolumn{2}{|l|}{ ERß1-Negative } & \multicolumn{2}{|l|}{ ERß1-Positive } & \multirow[t]{2}{*}{$r P$} \\
\hline & $\begin{array}{l}\text { No. of patients } \\
(n=56)\end{array}$ & $\%$ & $\begin{array}{l}\text { No. of patients } \\
(n=26)\end{array}$ & $\%$ & \\
\hline Age(years) & & & & & -0.0360 .749 \\
\hline$\leq 48$ & 28 & 50.00 & 14 & 53.85 & \\
\hline$>48$ & 28 & 50.00 & 12 & 46.15 & \\
\hline Tumor size(cm) & & & & & 0.0090 .936 \\
\hline$\leq 2$ & 22 & 39.29 & 10 & 38.46 & \\
\hline $2-5$ & 32 & 57.14 & 15 & 57.69 & \\
\hline$>5$ & 2 & 3.57 & 1 & 3.85 & \\
\hline Metastatic lymph nodes & & & & & $-0.3680 .001^{*}$ \\
\hline Negative & 15 & 26.79 & 17 & 65.38 & \\
\hline Positive & 41 & 73.21 & 9 & 34.62 & \\
\hline$A R$ & & & & & $0.3090 .005^{*}$ \\
\hline Negative & 48 & 85.71 & 15 & 57.69 & \\
\hline Positive & 8 & 14.29 & 11 & 42.31 & \\
\hline ZEB1 & & & & & $-0.3300 .003^{*}$ \\
\hline Negative & 19 & 33.93 & 18 & 69.23 & \\
\hline Positive & 37 & 66.07 & 8 & 30.77 & \\
\hline E-cadherin & & & & & $0.3910 .0001^{*}$ \\
\hline Negative & 47 & 83.93 & 12 & 46.15 & \\
\hline Positive & 9 & 16.07 & 14 & 53.85 & \\
\hline
\end{tabular}

ERß1-expressing cells. By examining clinical TNBC specimens, we found that the expression of ER $\beta 1$ was negatively correlated with ZEB1 expression and positively correlated with E-cadherin expression. The ARpositive TNBC specimens had a higher percentage of
ER $\beta 1$-positive samples compared to the AR-negative TNBC specimens.

There were several defects in the present study. For instance, the sample size was small, and there was a lack of complete information of clinical features. In addition,

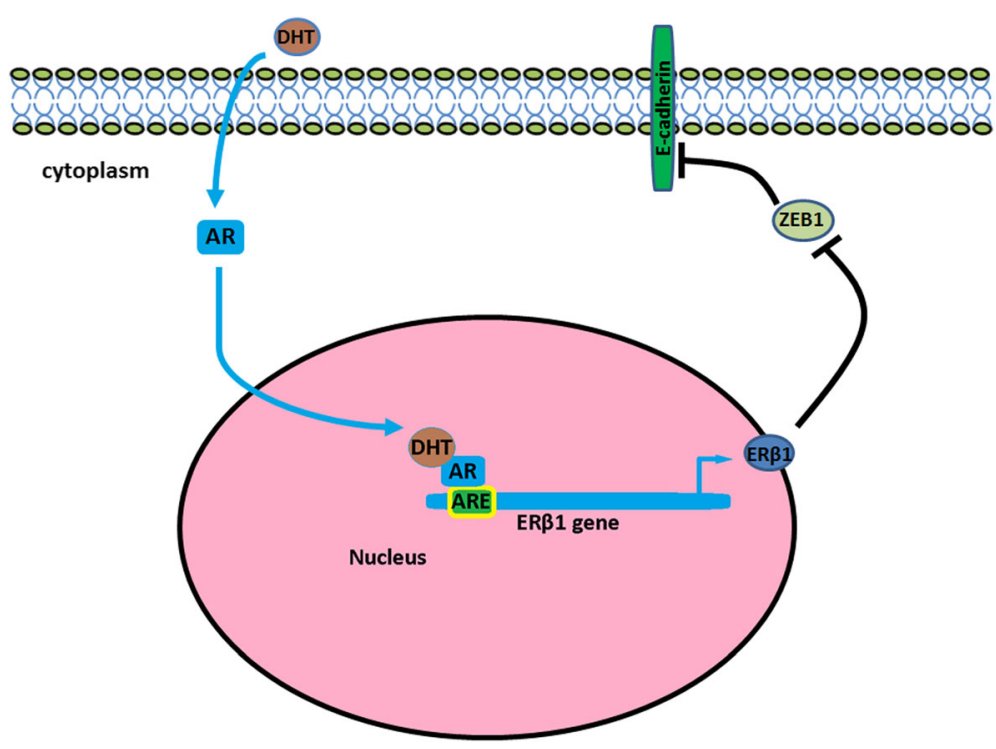

Fig. 7 Proposed working model of activated AR regulation of the transcription of ERß1, which subsequently suppresses ZEB1 
clinical samples originating from the metastasis lesion and not the primary lesion may be more relevant for the aim of this study. Future research should be performed to identify the binding site where AR binds to the promoter of ER $\beta 1$. Furthermore, follow-up records should be completed to allow correlation analyses with progression-free survival (PFS) and OS.

\section{Conclusions}

In summary, our work indicated that ER $\beta 1$ can inhibit metastasis of AR-positive TNBC through suppressing ZEB1. ER $\beta 1$ may play an important role in repressing invasive behavior and inhibiting metastasis in this subset of TNBC. Activated AR promotes ER $\beta 1$-induced metastasis inhibition of ER $\beta 1$-expressing TNBC cells (Fig. 7). The results provided the probable mechanism behind the anti-metastatic effect of ER $\beta 1$ and strengthened the possibility that ER $\beta 1$ can help to identify patients with AR-positive TNBC with lower risk to develop metastasis.

\section{Abbreviations}

AR: Androgen receptor; ATCC: American Type Culture Collection; DHT: Dihydrotestosterone; EMT: Epithelial-mesenchymal transition;

ERa: Estrogen receptor alpha; ERß1: Estrogen receptor beta 1; ER $\beta 2$ : Estrogen receptor beta 2; FBS: Fetal bovine serum; HER2: Human epidermal growth factor receptor 2; IHC: Immunohistochemistry; PR: Progesterone receptor; shAR: AR shRNA.; shNC: shRNA control; TNBC: Triple-negative breast cancer

\section{Acknowledgements}

Not applicable.

\section{Funding}

This work was supported by National Natural Science Foundation of China (No. 81470357) and a Foundation for Clinical Medicine Science and Technology Special Project of the Jiangsu Province, China (No. BL2014071) (to X. G).

\section{Availability of data and materials}

Please contact author for data requests.

\section{Authors' contributions}

X.G. and W.S. designed the study. W.S. wrote the main manuscript text; W.S conducted most experiments; L.T., Y.X., Q.S. and F.Y. provided professional advices during the whole research. All authors reviewed the manuscript. All authors read and approved the final manuscript.

\section{Competing interests}

The authors declare that they have no competing interests.

\section{Consent for publication}

Not applicable.

\section{Ethics approval and consent to participate}

The use of human tumor tissue and clinical data was approved by the Jinling Hospital's Ethics Committees. All patients gave their written informed consent. All animal experiments were conducted in accordance with the Guide for Care and Use of Laboratory Animal, and all experimental procedures involving mice were authorized by the Animal Ethics Committee of Jinling Hospital.

\section{Publisher's Note}

Springer Nature remains neutral with regard to jurisdictional claims in published maps and institutional affiliations.

\section{Author details}

'Department of Medical Oncology, Jinling Hospital, Southern Medical University, Guangzhou 510515, China. ²Department of Medical Oncology, Jinling Hospital, Medical School of Nanjing University, Nanjing 210002, China. ${ }^{3}$ Department of Medical Oncology, Jinling Hospital, Nanjing Medical University, Nanjing 210029, China.

Received: 16 January 2017 Accepted: 29 May 2017

Published online: 05 June 2017

\section{References}

1. Jamdade VS, Sethi N, Mundhe NA, Kumar P, Lahkar M, Sinha N. Therapeutic targets of triple-negative breast cancer: a review. Br J Pharmacol. 2015;172(17):4228-37.

2. Bianchini G, Balko JM, Mayer IA, Sanders ME, Gianni L. Triple-negative breast cancer: challenges and opportunities of a heterogeneous disease. Nat Rev Clin Oncol. 2016;13(11):674-90.

3. Jang G, Lee S, Ahn J, Jung K, Lee H, Gong G, Kim H, Ahn S, Ahn S, Kim S. Clinical features and course of brain metastases in triple-negative breast cancer: Comparison with HER2+ and other type. J Clin Oncol. 2009;27(15_suppl):1064.

4. Collins LC, Cole KS, Marotti JD, Hu R, Schnitt SJ, Tamimi RM. Androgen receptor expression in breast cancer in relation to molecular phenotype: results from the Nurses' Health Study. Mod Pathol. 2011;24(7):924-31.

5. Mrklic I, Pogorelic Z, Capkun V, Tomic S. Expression of androgen receptors in triple negative breast carcinomas. Acta Histochem. 2013;115(4):344-8.

6. Safarpour D, Pakneshan S, Tavassoli FA. Androgen receptor (AR) expression in 400 breast carcinomas: is routine AR assessment justified? Am J Cancer Res. 2014;4(4):353-68.

7. McGhan LJ, McCullough AE, Protheroe CA, Dueck AC, Lee JJ, Nunez-Nateras R, Castle EP, Gray RJ, Wasif N, Goetz MP, et al. Androgen receptor-positive triple negative breast cancer: a unique breast cancer subtype. Ann Surg Oncol. 2014;21(2):361-7.

8. McNamara KM, Yoda T, Miki Y, Nakamura Y, Suzuki T, Nemoto N, Miyashita M, Nishimura R, Arima N, Tamaki K, et al. Androgen receptor and enzymes in lymph node metastasis and cancer reoccurrence in triple-negative breast cancer. Int J Biol Markers. 2015;30(2):e184-189.

9. Sutton LM, Cao D, Sarode V, Molberg KH, Torgbe K, Haley B, Peng Y. Decreased androgen receptor expression is associated with distant metastases in patients with androgen receptor-expressing triple-negative breast carcinoma. Am J Clin Pathol. 2012;138(4):511-6.

10. Wang C, Pan B, Zhu H, Zhou Y, Mao F, Lin Y, Xu Q, Sun Q. Prognostic value of androgen receptor in triple negative breast cancer: A meta-analysis. Oncotarget. 2016;7(29):46482-91.

11. Mak P, Leav I, Pursell B, Bae D, Yang X, Taglienti CA, Gouvin LM, Sharma VM, Mercurio AM. ERbeta impedes prostate cancer EMT by destabilizing HIF1alpha and inhibiting VEGF-mediated snail nuclear localization: implications for Gleason grading. Cancer Cell. 2010;17(4):319-32.

12. Wang J, Zhang $C$, Chen $K$, Tang $H$, Tang J, Song C, Xie X. ERbeta1 inversely correlates with PTEN/PI3K/AKT pathway and predicts a favorable prognosis in triple-negative breast cancer. Breast Cancer Res Treat. 2015;152(2):255-69.

13. Zhou Y, Ming J, Xu Y, Zhang Y, Jiang J. ERbeta1 inhibits the migration and invasion of breast cancer cells through upregulation of E-cadherin in a Id1dependent manner. Biochem Biophys Res Commun. 2015;457(2):141-7.

14. Rosin G, de Boniface J, Karthik GM, Frisell J, Bergh J, Hartman J. Oestrogen receptors beta1 and betacx have divergent roles in breast cancer survival and lymph node metastasis. Br J Cancer. 2014;111(5):918-26.

15. Chantzi NI, Tiniakos DG, Palaiologou M, Goutas N, Filippidis T, Vassilaros SD, Dhimolea E, Mitsiou DJ, Alexis MN. Estrogen receptor beta 2 is associated with poor prognosis in estrogen receptor alpha-negative breast carcinoma. J Cancer Res Clin Oncol. 2013;139(9):1489-98.

16. Miller WR, Anderson TJ, Dixon JM, Saunders PT. Oestrogen receptor beta and neoadjuvant therapy with tamoxifen: prediction of response and effects of treatment. Br J Cancer. 2006;94(9):1333-8.

17. Wimberly H, Han G, Pinnaduwage D, Murphy LC, Yang XR, Andrulis IL, Sherman M, Figueroa J, Rimm DL. ERbeta splice variant expression in four large cohorts of human breast cancer patient tumors. Breast Cancer Res Treat. 2014;146(3):657-67.

18. Reese JM, Suman VJ, Subramaniam M, Wu X, Negron V, Gingery A, Pitel KS, Shah SS, Cunliffe HE, McCullough AE, et al. ERbeta1: characterization, prognosis, and evaluation of treatment strategies in ERalpha-positive and -negative breast cancer. BMC Cancer. 2014;14:749. 
19. Honma N, Horii R, Iwase T, Saji S, Younes M, Takubo K, Matsuura M, Ito Y, Akiyama F, Sakamoto G. Clinical importance of estrogen receptor-beta evaluation in breast cancer patients treated with adjuvant tamoxifen therapy. J Clin Oncol. 2008;26(22):3727-34

20. Nie W, Huang W, Zhang W, X J, Song W, Wang Y, Zhu A, Luo J, Huang G, Wang Y, et al. TXNIP interaction with the Her-1/2 pathway contributes to overall survival in breast cancer. Oncotarget. 2015;6(5):3003-12.

21. Yan M, Rayoo M, Takano EA. KConFab I, Fox SB: Nuclear and cytoplasmic expressions of ERbeta1 and ERbeta2 are predictive of response to therapy and alters prognosis in familial breast cancers. Breast Cancer Res Treat. 2011;126(2):395-405.

22. Dey P, Jonsson P, Hartman J, Williams C, Strom A, Gustafsson JA. Estrogen receptors beta 1 and beta 2 have opposing roles in regulating proliferation and bone metastasis genes in the prostate cancer cell line PC3. Mol Endocrinol. 2012:26(12):1991-2003.

23. Ito K, Park SH, Nayak A, Byerly JH, Irie HY. PTK6 Inhibition Suppresses Metastases of Triple-Negative Breast Cancer via SNAIL-Dependent E-Cadherin Regulation. Cancer Res. 2016;76(15):4406-17.

24. Yu JM, Sun W, Hua F, Xie J, Lin H, Zhou DD, Hu ZW. BCL6 induces EMT by promoting the ZEB1-mediated transcription repression of E-cadherin in breast cancer cells. Cancer Lett. 2015;365(2):190-200.

25. McEwan IJ, Gustafsson J. Interaction of the human androgen receptor transactivation function with the general transcription factor TFIIF. Proc Natl Acad Sci U S A. 1997;94(16):8485-90.

26. Metzger E, Wissmann M, Yin N, Muller JM, Schneider R, Peters AH, Gunther T, Buettner R, Schule R. LSD1 demethylates repressive histone marks to promote androgen-receptor-dependent transcription. Nature. 2005:437(7057):436-9.

27. Liedtke C, Mazouni C, Hess KR, Andre F, Tordai A, Mejia JA, Symmans WF, Gonzalez-Angulo AM, Hennessy B, Green M, et al. Response to neoadjuvant therapy and long-term survival in patients with triple-negative breast cancer. J Clin Oncol. 2008;26(8):1275-81.

28. Ahn SG, Kim SJ, Kim C, Jeong J. Molecular Classification of Triple-Negative Breast Cancer. J Breast Cancer. 2016;19(3):223-30.

29. Park S, Koo JS, Kim MS, Park HS, Lee JS, Lee JS, Kim SI, Park BW. Characteristics and outcomes according to molecular subtypes of breast cancer as classified by a panel of four biomarkers using immunohistochemistry. Breast. 2012;21(1):50-7.

30. Barton VN, D'Amato NC, Gordon MA, Christenson JL, Elias A, Richer JK Androgen Receptor Biology in Triple Negative Breast Cancer: a Case for Classification as AR+ or Quadruple Negative Disease. Horm Cancer. 2015;6(5-6):206-13.

31. Thomas C, Rajapaksa G, Nikolos F, Hao R, Katchy A, McCollum CW Bondesson M, Quinlan P, Thompson A, Krishnamurthy S, et al. ERbeta represses basal breast cancer epithelial to mesenchymal transition by destabilizing EGFR. Breast Cancer Res. 2012;14(6):R148.

32. Oka H, Shiozaki H, Kobayashi K, Inoue M, Tahara H, Kobayashi T, Takatsuka Y, Matsuyoshi N, Hirano S, Takeichi M, et al. Expression of E-cadherin cell adhesion molecules in human breast cancer tissues and its relationship to metastasis. Cancer Res. 1993;53(7):1696-701.

33. Onder TT, Gupta PB, Mani SA, Yang J, Lander ES, Weinberg RA. Loss of E-cadherin promotes metastasis via multiple downstream transcriptional pathways. Cancer Res. 2008;68(10):3645-54.

34. Tang $D, X u S$, Zhang $Q$, Zhao $W$. The expression and clinical significance of the androgen receptor and E-cadherin in triple-negative breast cancer. Med Oncol. 2012;29(2):526-33.

35. Graham TR, Yacoub R, Taliaferro-Smith L, Osunkoya AO, Odero-Marah VA, Liu T, Kimbro KS, Sharma D, O'Regan RM. Reciprocal regulation of ZEB1 and AR in triple negative breast cancer cells. Breast Cancer Res Treat. 2010;123(1):139-47.

\section{Submit your next manuscript to BioMed Central and we will help you at every step:}

- We accept pre-submission inquiries

- Our selector tool helps you to find the most relevant journal

- We provide round the clock customer support

- Convenient online submission

- Thorough peer review

- Inclusion in PubMed and all major indexing services

- Maximum visibility for your research

Submit your manuscript at www.biomedcentral.com/submit
Biomed Central 